Trivent Publishing

(C) The Authors, 2016

Available online at http://trivent-publishing.eu/

Series: Philosophy, Communication, Media Sciences

Volume: Communication Today: An Overview from Online Journalism to Applied Philosophy

\title{
CLIL in the Knowledge Society
}

\section{Suzana Carmen Cismas, ${ }^{1}$ Ion Dona, ${ }^{2}$ Gabriela Ionela Andreiasu ${ }^{3}$}

${ }^{1}$ Faculty of Management, Economic Engineering in Agriculture and Rural Development, University of Agronomic Sciences and Veterinary Medicine, Bucharest, Romania, suzanacismas@yahoo.com

${ }^{2}$ Faculty of Management, Economic Engineering in Agriculture and Rural Development, University of Agronomic Sciences and Veterinary Medicine, Bucharest, Romania, ion_dona@yahoo.com

${ }^{3}$ Polytechnic University of Bucharest, Bucharest, Romania, gabriela_bucata@yahoo.com

\begin{abstract}
CLIL - Content and Language Integrated Learning - is an evolving approach where subjects are taught and studied through a non-native language, which is more challenging and intensive, as there is more idiom exposure and the students acquire knowledge and skills in various areas of the modern curriculum required by the global markets and the knowledge society.

All CLIL subjects stem from the issues that define the knowledge society: active citizenship, business, engineering, management, marketing, technology, environment, information and communication, literacy and social sciences. This approach forms confident graduates with enhanced academic pro-cessing strategies and communication skills, able to favour intercultural understanding and foster community values.
\end{abstract}

\section{Keywords}

CLIL; knowledge society; modern integrated curriculum; intercultural approaches; global values.

This is an Open Access article distributed in accordance with the Creative Commons Attribution Non Commercial (CC-BYNC-ND 4.0) license, which permits others to copy or share the article, provided original work is properly cited and that this is not done for commercial purposes. Users may not remix, transform, or build upon the material and may not distribute the modified material (http://creativecommons.org/licenses/by-nc/4.0/)

DOI: 10.22618/TP.PCMS.20164.349018 


\section{CLIL, globalisation, and the modern information society}

CLIL induces more intense cognitive activity throughout the learning process, with lessons centred on topics and idea clusters. The target is stimulating the linguistic intelligence by enhancing reasoning and communication practice across cultures, enabling students to experiment ${ }^{1}$ and take risks with new languages and argumentative strategies. Professors assume new roles, becoming facilitators and gobetweens who focus students' real interests, aims, and needs in a time-effective manner - a synthesis across the curriculum to better use the limited classroom interval. They implement new methods, ${ }^{2}$ materials and approaches, mostly in virtual learning contexts, capitalising on direct experience and inter-national, individual as well as institutional networking or professional mobility. Language acquisition and discourse analysis in content subjects are domains with strong traditions and history. Engineering, business, medicine, agronomy and law are areas with their own specialized strategies in delivering language for specific topics. Professors' aim is to successfully implement discourse analysis techniques to all education levels, in view of identifying curricula language accessible to all learners working in a second idiom. There has been constant pressure exerted by different factors and events generating change in this domain over the last quarter of a century, as visible in the diagram below:

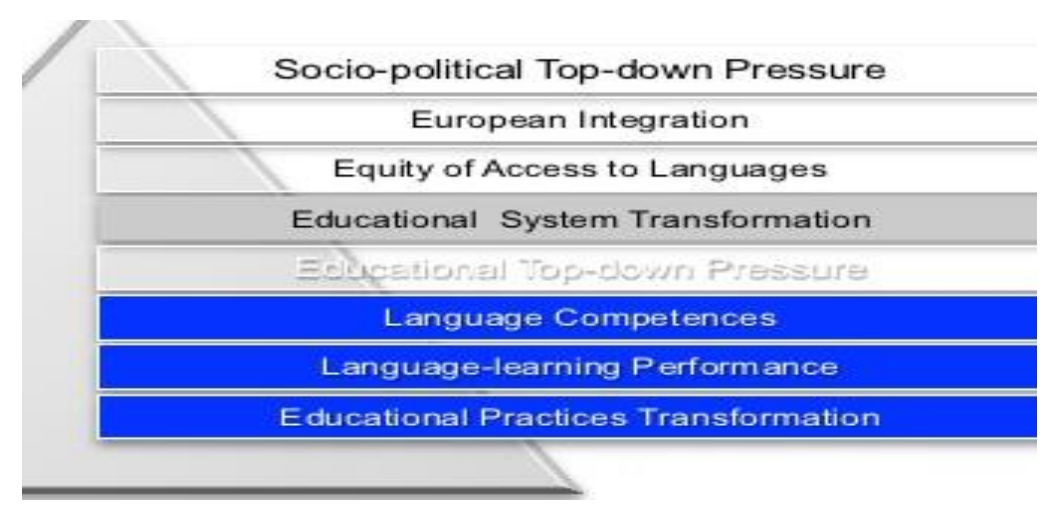

Fig. 1. Pressure for increased adequacy in 1990-2000, cf. euridyce.org 2014

As intended, and in step with the challenges of the knowledge society, the professionals educated by CLIL seem more tolerant of diverse backgrounds and better equipped for lifelong learning and for constant professional development to meet the standards of flexible job markets.

New study types emerge and include, besides the formal ones (organized, intentional, structured), the non-formal ones (with no credits, but organized), as well as the informal learning (spontaneous, lacking organization). In them all, each subject has its own set of skills, some specific and some common across subjects. For example, research requires sub-skills for data processing (collection, prioritising, essay writing) alongside with presenting data to a group. Hence the specific language demands the teacher will identify, practise, and support for the learner to become able to acquire the language proficiently. In this respect, the Digital Era radically changed both learning and teaching skills and approaches.

Thought-provoking content is delivered by multimedia, generating innovative ${ }^{3}$ and motivating approaches, contexts and techniques for practising the key skills to further use in education as well as careers. The resulting labour force demonstrates improved self-esteem and self-reliance, alongside with increased inter-cultural and cross-cultural awareness. Increasing numbers of universities tend to grant CLIL wider implementation, as a result of acknowledging its strategic benefits.

\footnotetext{
${ }^{1}$ Corrales, K., Maloof, C., Student perceptions on how content-based instruction supports learner development in foreign language contexts (Spanish edition. Madrid: Zona Próxima, 2011), 40-53.

2 Tarja Nikula, Dalton-Puffer, Linares, "CLIL classroom discourse," in Journal of Immersion and Content-Based Language Education 1 (2013): 70-100.

${ }^{3}$ Mendelson, A, Using Online Forums to Scaffold Oral Participation in Foreign Language Instruction, eproceedings of the International On-line Language Conference (IOLC 2009).
} 
The wide-ranging goals include ${ }^{4}$ : progress of intercultural communication skills; internationalism; chances to study content by other angles; subject-specific terminology in foreign idioms; competence and better communication skills; increased student motivation.

\section{Didactic developments in the knowledge society: from ESP to CLIL}

Both CLIL and ESP are constructed on principles of effective learning, not on specific methodologies; all decisions aim at learners' needs. The most important goal is the ability to transfer knowledge and idiom from one area to another.

Historically speaking, ESP (English for Specific Purposes) emerged in the 1960s, 30 years prior to CLIL, and both stem from the common demands of world economy, from the emergence of English as international language of communication in science and business, and from the new focus on responding to learners' needs of dialogue in specific contexts.

ESP was successful in academic language teaching as a result of using the communicative approach. It shares with CLIL the following characteristics:

- Vocabulary intended for intermediate/advanced adult students with basic English knowledge.

- Methods and activities consistent the subject served;

- Language practice fit for the discipline in different contexts.

- Focus on career purposes and academic study skills, mainly learning to learn.

- Authentic learning materials, suitable for students' actual proficiency levels.

In parallel, in 1965, Content-Based Teaching (CBT) and the Canadian Immersion Model laid the bases for learning content in a second language. ${ }^{5}$ ESP and CBT dealt with occupational needs which required both content and language with the same priority.

In 1994, similar demands led to the emergence of CLIL in Europe which is a stand-alone approach melting socio-culturalism, constructivism, multiple intelligences and language learning theories, but CLIL and CBI share common traits ${ }^{6}$, both fusing content and idiom. In addition to this, CLIL has incorporated ideas from EFL, ESP, TBI (Task-Based Instruction) and related disciplines. In all the above, content and language merge consistently, so we wonder where ESP ends and CLIL begins.

\section{Students' needs emerging from the perspective of their future careers}

Integrating language learning, vocational knowledge and skills is vital in motivating students. Just as it happens with students in the contemporary knowledge society we live in, with its increasing demands and heightened levels of activity, CLIL learners feel overwhelmed, so teachers implicitly give coping mechanisms by designing student-centred working/learning strategies, where students choose texts and projects of interest. As a result, they can select the reading style and speed, to alleviate stress or pressure, so that they better control the learning process independently. Authentic materials make study relevant and necessary, so language learning is not an object of study per se. Discourse proficiency in any content subject is already a field of linguistics with a very strong tradition and history ${ }^{7}$. Law, medicine, engineering and business are just three areas which have their own bodies of specialized study for delivering specific language for such subjects. CLIL is an attempt to bring discourse analysis techniques to all education levels, with a view to identifying the curricula language so that it can be made accessible for learners working via a second idiom. This refers to language in the context of skills which occur in many subject areas across the curriculum, defined as a general academic language, since it is not specific to one subject strictly.

\footnotetext{
${ }^{4}$ Dalton-Puffer, C, "Outcomes and Processes in Content and Language Integrated Learning, current research from Europe," in Future Perspectives for English Language Teaching (Heidelberg: Carl Winter, 2007), 268.

5 Coyle, D., "Evaluating the impact of CLIL programmes," in Content and Language Integrated Learning (Cambridge, Cambridge English, 2010), 275.

6 Coyle, D., Research Report Investigating Student Gains, Content and Language Integrated Learning, (Aberdeen: University of Aberdeen Publishing House, 2011), 134.

${ }^{7}$ EURYDICE, L'enseignement d'une matière intégré à une langue étrangère, European Commission, $2006,23$.
} 


\section{CLIL stimulating independent study for lifelong learning}

A key aim of CLIL teaching is to help students work independently to solve problems and develop their own knowledge as well as skills. It is the most successful didactic learner autonomy instrument, consistent with the graduates' lifelong learning framework. This approach closely connects with learners' lives, needs and interests, encouraging student-to-student communication, learning and decision-making on content and language, as well as on assessment criteria. In certain cases, studentgenerated rules are accepted, allowing them to ask for new input when they need it, as opposed to the teaching in advance of words that professors think learners might need. CLIL adds extrinsic motivation for males while female students show intrinsic motivation. ${ }^{8}$ It may reduce the well-known gender differences in foreign idiom competences between males and females as seen in research studies in many contexts (females are more inclined to study foreign languages and they usually outperform their male counter-parts). However, CLIL does not eradicate gender gaps. As not all students work in the same way, they are advised to recognise and develop their own learning styles and strategies. Instilling autonomy will result in better learning. CLIL differs from traditional education: rather than focus on a single subject, it includes all the goals, involving competences, knowledge, skills, attitudes and behaviour. Students' particulars are taken into account in preparing such curricula and assessment, for enhancing independent study. ${ }^{9}$ Cultivating thinking skills is needed for academic discourse functions, for revealing the inter-section of content, cognition and idiom, and for the ability to express complex thought processes adequately. Cognitive skills are crucial and systematic language work is important in teaching thinking. Students need to be shown how to express their ideas in an increasingly complex manner. ${ }^{10}$ Teaching thinking skills uses modern re-conceptions of the traditional taxonomy published by Bloom in 1956 and revised by Anderson and Krathwohl. To highlight the marked progress achieved by CLIL we correlate the taxonomies with the learning pyramid that shows the percentage of learning achieved by various activities, as published by the National Training Laboratories, Maine:
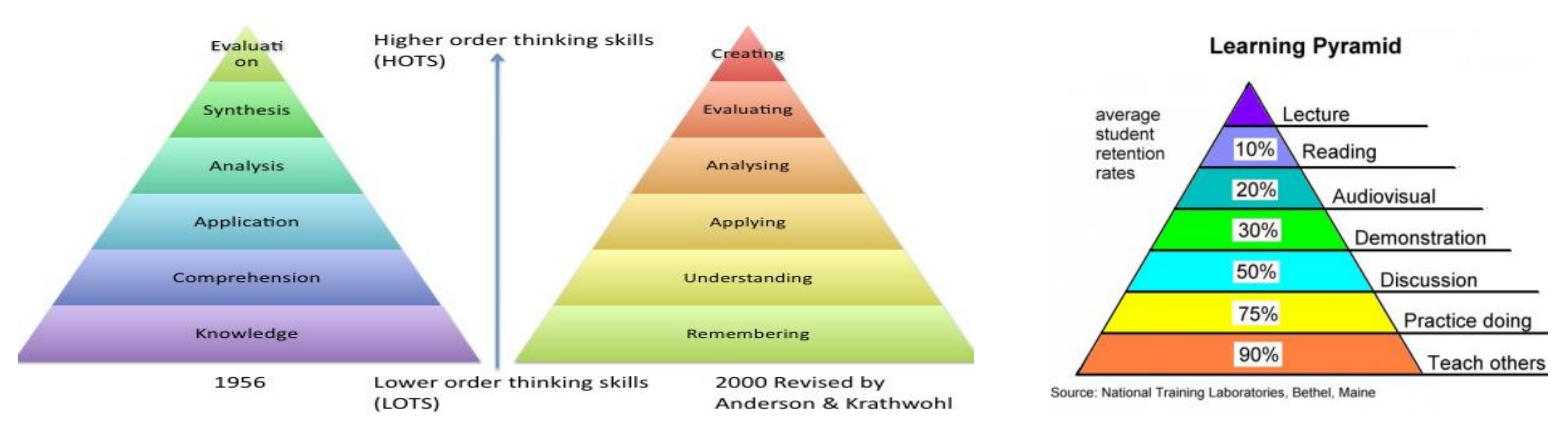

Fig. 2. Bloom's taxonomy revised by Anderson and Krathwohl, and the learning pyramid, www.alte.org

This categorization and hierarchy of cognition skills maps the way lower order thinking skills ideally lead to training the higher order ones. Some routine content-processing tasks reinforce cognition: note-taking needs sequencing process steps; identifying cause and effect; expressing relations; outlining a topic from text/audiovisual media; commenting. At times priority shifts from content to accurate idiom use. The figure shows the complex ensemble of independent study strategies, providing a glimpse into the difficulty of teaching them in an integrated manner.

\footnotetext{
${ }^{8}$ Bonnett, A, "Towards an Evidence Base for CLIL: How to Integrate Qualitative, Quantitative and Process, Product and Participant Perspectives," in CLIL Research. International CLIL Research Journal 1(2012): 35.

9 Jäppinen, A-K., "Thinking and Content Learning of Science as Cognitional Development in Content and Language Integrated Learning (CLIL)," in Teaching by a Foreign Language in Finland Language and Education, an International Journal 19 (2005): 148-169.

${ }^{10}$ ECML, Content and language integrated learning through languages other than English - Getting started, Council of Europe, 2006, 37.
} 
Assessment increases learner autonomy: students see the learning target and identify and close gaps. Learner autonomy is fostered by students suggesting test criteria; self- and peerassessment further encourage the reluctant ones.

\section{CLIL professors as promoters of the knowledge society}

CLIL has its own pedagogic pattern and professors must adjust to a new set of language-supportive task types, never present or anticipated in the mother tongue; thus professors ${ }^{11}$ develop a different quality of didactic talk, with varied interaction forms. It is preferable that there is cooperation between the content and the language professors when establishing CLIL programs (Pavesi, 2001). However, it is not always possible or feasible, and CLIL teachers often have to perform both roles. This may generate anxiety when teachers who are knowledgeable about their subject areas but who are not proficient in the target language are asked to do CLIL. They never use the type of communication students usually learn in language classes. As CLIL students do not learn language by topics in language handbooks, like family, travel, advertising, CLIL professors do not convey Basic Interpersonal Communication Skills (BICS).

CLIL learners are more successful and motivated than those in traditional content education because they regard the content from different and broader perspectives when taught in another idiom; they develop more accurate academic concepts; in CLIL, subject-related intercultural learning takes place. Hence it all is highly demanding for professors, and not all are willing to work extra, on uncharted areas. Furthermore, there is no specific methodology that relates to CLIL, and it requires active methods, co-operative classroom management ${ }^{12}$, and emphasis on all communication types. Moreover, holistic ways of learning as well as learning from practical, hands-on experience need to be used. In CLIL, it is important to use audio-visual aids and multimedia in order to overcome issues caused by the use of a new language; hence the need for well-equipped classrooms.

The simultaneous teaching of a second language and certain content should include language support like reformulation, simplification and exemplification. CLIL professors are bi/pluri-lingual. Code switching (switching to the students' school lingua franca instead of the target idiom) should be the last option for communication purposes, but a mixture of both languages, so as to get messages across effectively or keep the conversation going may be permitted. Therefore teamwork skills are needed by CLIL professors in preparing the curriculum and while teaching, which is difficult. Students should spend $50 \%$ of all lessons using the target idiom, focusing on the oral skills: speaking and listening.

When planning the CLIL curriculum, it is important and challenging to take into account:

- Learners' ages, needs, interests, motivation and general linguistic competence

- Teacher's competences, training and expertise in CLIL and command of the second language

- Administrative support in school and its resources

- Local community interest; resources to achieve the outcomes and objectives they all set.

Through interaction with peers and teachers, and by use of multimedia resources, each student constructs new knowledge at his own pace, going from simple awareness to real understanding and proficiency. Hence teacher training and constant development must be enforced. Teachers require specialised training in language pedagogy, alongside with the didactics of academic subjects. Academic policy is important, especially for CLIL administration and management. As the integration of theory and practice is fundamental to the success of CLIL training, it should include observation in such classes, training sessions at university, didactic instruction and training placements in universities in the target-language country. Continuing professional development ${ }^{13}$ (CPD) keeps the staff updated

${ }^{11}$ Cismas, S.C., Dona, I., Andreiasu, G.I., "CLIL Supporting Academic Education in Business Engineering Management," in Recent Research in Engineering Education, Proceedings of the 11th International Conference on Engineering Education (Salerno: WSEAS Press), 78-88.

${ }^{12}$ Alonso, E., Grisaleña, J, "Plurilingual Education,” International CLIL Research Journal 1 (2008): 54.

${ }^{13}$ Navés, T., Muñoz, C., Usar las lenguas extranjeras para aprender, y aprender a usar las lenguas extranjeras. TIE-CLIL EUproject, 2000, www.ec.europa.eu/education/policies (accessed 6 July, 2016). 
and informed on the latest and most relevant developments in the field. For CPD, the main prerequisite is to attract committed subject teachers who feel confident of their subject matter and are experts in their subject specialist language, teaching methodologies and syllabus. They must be able to communicate in the target idiom but also assist students in developing language awareness. The key aspects of effective in-service CLIL teacher education are: language work, particular strategies for text comprehension and lexis acquisition; development of ways to fuse content and language. The ECML framework for the professional development of CLIL professors ${ }^{14}$ specifies professional competences CLIL teachers should possess:

- Commitment to cognitive and social development;

- Research-based knowledge of the interdependence of language and cognitive development;

- An active learning model by showing a personal way of enquiry, reflection and evaluation;

- Provide CLIL-specific resources and enriched study environments (highly integrative, multilayered, cognitively demanding, but balanced by systems);

- Classroom management via modern group dynamics and motivation techniques;

- Building common knowledge among stakeholders on program management and each other's role in supporting development.

The professor uses systematic but flexible methods to improve educational practices by design, analysis, development and implementation, relying on cooperation among researchers and practitioners in real-world settings. The methodology is pragmatic, conducted in actual settings, flexible, interactive (designers work together with participants), integrative (mixed research methods are used, and modalities vary in different phases), and contextual (research results are connected with the design process and the setting). Therefore the CLIL professional will demonstrate certain indispensable traits:

- Flexibility and teamwork skills;

- Skills in highlighting important items, going back to crucial points by rewording, rephrasing and giving new perspectives; text marker role analysis (logical flow, time-sequencing, cause-effect);

- Practical in monitoring and assessing the process, the product and the project, subsequently testing students' gaps in content or language separately;

- Assessment melted into work activities and exercises;

- Optimal education strategies are problem solving, content mapping, and concept elaboration, practising communication skills, and manifesting attitudes;

Attention shifts from language to content depending on geopolitical contexts ${ }^{15}$, on the degree of similarity between the foreign idiom and the students' mother tongue, the subject being taught through the foreign language, local resources, the same teacher certified in both the language and the content subject, or different teachers collaborating and/or present in class simultaneously. In CLIL focusing mostly on language, the foreign idiom expert works on the content already acquired through the other discipline. Teaching modules are constantly set up on the Internet for group work with university students across various academic subjects.

\section{Conclusions}

CLIL is designed to prepare young people for the future careers. CLIL stemmed from the communicative approaches influenced by autonomous learning, student mobility programs, and new technologies.

\footnotetext{
${ }^{14}$ Marsh, D, Mehisto, P, Wolff, D, Jesús Frigols Martín, M, European Framework for CLIL Teacher Education, Framework for professional development of CLIL teachers, 2011, www.ec.europa.eu/education/policies (accessed 6 July, 2016).

${ }^{15}$ Casado, J, García, M, “Consideraciones didácticas sobre la enseñanza de lenguas” in Didáctica (Lengua y Literatura) 12 (2000): 67-89.
} 
Hence language policies regard CLIL as a means for internationalizing and modernizing institutional profiles. Content in tertiary education is an opportunity for CLIL learners to master specific lexis competences ${ }^{16}$ indispensable in furthering their studies and gaining an edge.

It outlines steps to understanding and learning independently and has three main features:

- The learning of an additional idiom is integrated in content subjects such as science. Students learn the target language through which the content is facilitated.

- CLIL has its origin in different socio-linguistic and political contexts; it relates to any language, age and education level from primary, secondary, and higher to vocational and professional learning. In this sense CLIL responds to the EU lifelong learning program; multilingualism and multiculturalism promote understanding, integration and mobility for all Europeans.

- CLIL cultivates social, cultural, cognitive, linguistic, and academic study skills, which, in turn, facilitate achievements in both content and idiom.

The important reason for the introduction of CLIL is to help the education sector prepare students for the world of work today and tomorrow ${ }^{17}$.

\begin{tabular}{|c|c|}
\hline Factors encouraging CLIL & Factors hindering CLIL \\
\hline $\begin{array}{l}\text { Schools in primary and lower secondary } \\
\text { education offering CLIL with the opportunity } \\
\text { to transfer and progress in a CLIL } \\
\text { environment }\end{array}$ & $\begin{array}{l}\text { Patchy provision of CLIL which impedes } \\
\text { pupil transfer an d provides limited } \\
\text { opportunities for CLIL practice in initial } \\
\text { teacher training }\end{array}$ \\
\hline $\begin{array}{l}\text { Limited opportunities for language learning } \\
\text { in the curriculum }\end{array}$ & $\begin{array}{l}\text { Relatively good foreign language teaching } \\
\text { outcomes without CLIL and opportunities for } \\
\text { non-formal and informal learning of } \\
\text { languages, especially English }\end{array}$ \\
\hline \multirow[t]{2}{*}{$\begin{array}{l}\text { Teachers with language competences and } \\
\text { experience of submersion teaching }\end{array}$} & $\begin{array}{l}\text { Language competences of subject teachers } \\
\text { need to be raised; special courses and } \\
\text { training outside the school }\end{array}$ \\
\hline & $\begin{array}{l}\text { Teacher training for CLIL/bilingual teaching } \\
\text { not available }\end{array}$ \\
\hline $\begin{array}{l}\text { Communities of practice among CLIL } \\
\text { teachers and schools }\end{array}$ & $\begin{array}{l}\text { Limited continuing professional } \\
\text { development to support CLIL schools and } \\
\text { teachers }\end{array}$ \\
\hline $\begin{array}{l}\text { Internationalisation and globalisation of } \\
\text { current society; high levels of mobility } \\
\text { among young people with vocational and } \\
\text { HE qualifications and recognised needs for } \\
\text { foreign language competency for }\end{array}$ & $\begin{array}{l}\text { Lack of systematic guidelines to } \\
\text { implementing CLIL and support for CLIL at } \\
\text { the national level }\end{array}$ \\
\hline
\end{tabular}

Fig. 3. Factors facilitating and hindering CLIL, (Coyle, Content Language Integrated Learning, 2010)

Universities and authorities benefit from using the CLIL framework of competences, as it requires development (not establishment) costs, and needs didactic flexibility ${ }^{18}$ to accommodate the curricular demands. The academic environment should be able to introduce CLIL for specific groups as an option, thus promoting an appealing profile for the coming students. CLIL generates plausible

\footnotetext{
${ }^{16}$ Braquier, C., En quoi l'enseignement en langue étrangère d'une discipline non linguistique influence-t-elle les représentations qu'ont les élèves de cette LVE? Institut Universitaire de Formation des Maîtres (Artois : Ecole Interne de l'Université d'Artois, 2013), 65.

${ }^{17}$ Cismas, S.C., Dona, I., Andreiasu, G.I., "Tertiary Education via CLIL in Engineering and Management," in Recent Research in Engineering Education, Proceedings of the 11th International Conference on Engineering Education (Salerno: WSEAS Press), 134-142.

${ }^{18}$ Ruiz de Zarobe, Y, "CLIL implementation: From policy-makers to individual initiatives," International Journal of Bilingual Education and Bilingualism 16 (2013): 231-243.
} 
explorative learning approaches where students work collaboratively on projects, collecting, discussing, and designing new materials, which, in turn, creates pathways for graduates to make a successful transition to the labour market and build on the benefits of increased communication competence. Resources are built and dynamically transformed by users via various available media and communication channels, into different representations reflecting cultural and linguistic diversity.

The universities will obtain more visibility and increased internationalization, as CLIL is more credible and content wise than the traditional visions. Project work is easier to embed into CLIL than into conventional didactics as critical framing and analyzing results situate work in its context. Comments, criticism and idea exchanges are supported by the learning environment; the whole activity fosters the information access process: information retrieval by searching/browsing, results analysis and synthesis.

CLIL requires adjustment in methodology to ensure that students understand the content, so professors have to think of other ways (group work tasks, debates and discussions) to actively involve learners while providing extra feedback opportunities.

CLIL diminishes the impact of socio-cultural status and mobilises lower ability learners' performance. They are more motivated towards independent study and self-confidence increases as they take risks and deal with real issues at the centre of their study.

\section{References}

Alonso, E., Grisaleña, J, Plurilingual Education, International CLIL Research Journal, issue 1, 2008.

Bonnett, A, Towards an Evidence Base for CLIL: How to Integrate Qualitative and Quantitative as well as Process, Product and Participant Perspectives in CLIL Research. International CLIL Research Journal, issue 1, 2012.

Braquier, C., En quoi l'enseignement en langue étrangère d'une discipline non linguistique influencet-elle les représentations qu'ont les élèves de cette LVE? Institut Universitaire de Formation des Maîtres, Ecole Interne de l'Université d'Artois, 2013.

Casado, J, García, M, Consideraciones didácticas sobre la enseñanza de lenguas. Didáctica (Lengua y Literatura), número 12, 2000, pp. 67-89.

Cismas, S.C., Dona, I., Andreiasu, G.I., CLIL Supporting Academic Education in Business Engineering Management, pp. 78-88, in Recent Research in Engineering Education, Proceedings of the 11th International Conference on Engineering Education, Salerno, Italy, ISSN: 2227-4618, ISBN: 978-1-61804-312-2, WSEAS Press - World Scientific and Engineering Academy and Society, 2015

Cismas, S.C., Dona, I., Andreiasu, G.I., Tertiary Education via CLIL in Engineering and Management pp.134-142, in Recent Research in Engineering Education, Proceedings of the 11th International Conference on Engineering Education, Salerno, Italy, June 27-29 2015, ISSN: 2227-4618, ISBN: 978-1-61804-312-2, WSEAS Press - World Scientific and Engineering Academy and Society Press, 2015

Corrales, K., Maloof, C., Student perceptions on how content-based instruction supports learner development in foreign language contexts (Spanish version), pp. 40-53, Zona Próxima, 2011.

Coyle, D., Evaluating the impact of CLIL programmes, in Content and Language Integrated Learning, Cambridge English, 2010.

Coyle, D, Research Report Investigating Student Gains, Content and Language Integrated Learning, University of Aberdeen, 2011.

Dalton-Puffer, C, Outcomes and Processes in Content and Language Integrated Learning, current research from Europe, in Future Perspectives for English Language Teaching, Carl Winter, Heidelberg, 2007.

ECML, Content and language integrated learning through languages other than English - Getting started, Council of Europe, 2006.

EURYDICE, L'enseignement d'une matière intégré à une langue étrangère à l'école en Europe, European Commission, 2006. 
Jäppinen, A-K., Thinking and Content Learning of Science as Cognitional Development in Content and Language Integrated Learning (CLIL), Teaching by a Foreign Language in Finland Language and Education, an International Journal, issue 19, 2005, pp. 148-169.

Marsh, D., Mehisto, P., Wolff, D., Jesús Frigols Martín, M., European Framework for CLIL Teacher Education, Framework for professional development of CLIL teachers, 2011, retrieved from www.ec.europa.eu/education/policies

Mendelson, A, Using Online Forums to Scaffold Oral Participation in Foreign Language Instruction, e-proceedings of the International On-line Language Conference IOLC2009, pp. 8-22.

Navés, T., Muñoz, C., Usar las lenguas extranjeras para aprender, y aprender a usar las lenguas extranjeras. TIE-CLIL EUproject, 2000.

Raby, F, E.S.C.A.L.E Rapport de recherche: La dynamique des apprentissages, Evaluation d'un Scenario de Cyber Apprentissage d'une Langue Etrangère, École de Sciences Cognitives, 2008.

Ruiz de Zarobe, Y, CLIL implementation: From policy-makers to individual initiatives, International Journal of Bilingual Education and Bilingualism issue 16, 2013, pp. 231-243.

Tarja Nikula, Dalton-Puffer, Linares, CLIL classroom discourse, Journal of Immersion and ContentBased Language Education, issue 1, 2013, pp. 70-100. 